\title{
Prevalence of anti-hepatitis $C$ virus antibodies in pregnant women and their offspring in a tertiary hospital in Southwestern Nigeria
}

\author{
Paul Sunday Ogunro, ${ }^{1}$ Daniel Adebode Adekanle ${ }^{2}$ Francis Folorunso Fadero, ${ }^{3}$ \\ Titus Olabisi Ogungbamigbe, ${ }^{4}$ Samuel Olorunyomi Oninla. ${ }^{3}$ \\ ${ }^{1}$ Departments of Chemical Pathology, ${ }^{2}$ Obstetric/Gynaecology, ${ }^{3}$ Paediatrics and ${ }^{4}$ Pharmacology, College of Health Sciences, \\ Ladoke Akintola University of Technology, Osogbo, Nigeria.
}

\begin{abstract}
Background: The aim of this prospective study was to determine the prevalence of HCV antibodies among pregnant women and their corresponding offspring in a tertiary medical centre in Southwestern Nigeria.

Method: Anti-HCV antibodies (anti-HCV antibodies) were analyzed in blood samples from mothers and cord samples from their corresponding offspring using the Enzyme Linked Immunosorbent Assay (ELISA) method. The results obtained from the study were expressed in simple percentages.

Results: Out of the 272 consenting pregnant women screened for anti-HCV antibodies, 25 (9.2\%) of them were positive. As none of the pregnant women had multiple births, screening the 272 cord sera from their offspring for the same antibodies revealed that $3(1.10 \%)$ of them were also positive. Thus, the prevalence of anti-HCV antibodies in the pregnant women and their offspring were $9.2 \%$ and $1.1 \%$ respectively.

Conclusion: If vertical transmission of HCV were to be based on the acquisition of anti-HCV antibodies alone, the prevalence of vertical transmission from HCV infected mothers to offspring in the study was $12.0 \%$. Further studies on vertical transmission are suggested to include analysis for HCV-RNA quantification in pregnant mothers and their offspring as well as a long-term follow-up of neonates seropositive for HCV markers. Such studies are necessary to justify any recommendations to be made for the purpose of reducing HCV infection through vertical transmission.
\end{abstract}

Key Words: Prevalence, Hepatitis C Virus (HCV), anti-HCV antibodies, HCV-RNA Vertical Transmission.

J Infect Developing Countries 2007; 1(3):333-336.

Received 2 August 2007 - Accepted 19 November 2007.

Copyright (@) 2007 Ogunro et al. This is an open access article distributed under the Creative Commons Attribution License, which permits unrestricted use, distribution, and reproduction in any medium, provided the original work is properly cited.

\section{Introduction}

Hepatitis $\mathrm{C}$ virus (HCV) infects the liver and multiplies in the organ for many years; while some infected individuals live with the virus without major health problems as chronic carriers, a sizable proportion of the rest succumb to cirrhosis and cancer of the liver [1].

The global prevalence of $\mathrm{HCV}$ infection is estimated to be approximately $3 \%$ (170 million) of the world's population; the virus accounts for about $20 \%$ and $70 \%$ of cases of acute and chronic hepatitis respectively [2,3]. Africa is reported to have the highest prevalence rate for HCV [4] as there exists worldwide considerable geographical variation in its prevalence, ranging from as low as $0.01-0.1 \%$ in the United Kingdom and Scandinavia to as high as 17-26\% in Egypt [5].

There are various routes of transmission of $\mathrm{HCV}$ but direct percutaneous inoculation is the most efficient [6]. The Anti-HCV screening of blood and blood products introduced during the early 1990s has minimized transfusion of blood and blood products as a major mode of HCV acquisition [7]. Several studies have demonstrated that sexual, household, occupational, and vertical transmissions from mother to offspring are of some significance in the transmission of HCV [6].

Most studies conducted in the developed world have shown low prevalence rates on the vertical transmission of HCV $[8,9,10]$. In Africa, such studies had been conducted mainly in Egypt and Morocco $[11,12,13,14]$ with rates of transmission from HCV-RNA positive mothers ranging from $0 \%$ to $36 \%$. In sub-Saharan Africa, however, a study conducted in Tanzania among 980 pregnant women with a seroprevalence of $5 \%$ for $\mathrm{HCV}$ showed only one child to be HCV-RNA positive at 18 months of age [15]. 
Theoretically, vertical transmission of $\mathrm{HCV}$ from mother to offspring may occur at conception, in utero and during the perinatal period; however, its mechanisms, including timing, remain largely unknown [16]. Vertical transmission also remains the only route of acquisition of the virus by children in most developed countries [17]. While some studies have shown that vertical transmission rate for HCV was significantly higher for vaginally delivered infants compared with infants delivered by cesarean section [18], a review by the Centre for Disease Control in the USA [19] indicated no significant differences between these two modes of delivery. Although HCV-RNA has been found in breast milk samples, there is no evidence that suggests breastfeeding is a vehicle of $\mathrm{HCV}$ transmission from mother to offspring $[17,20]$.

It is pertinent to note that the most significant factor in vertical transmission from mother to offspring is a high maternal HCV viral load at the time of delivery $[19,21]$. A high level of maternal Alanine Aminotransferase (ALT) is also in support of vertical transmission [11].

In the newborn period and beyond, evidence of contact with the HCV includes demonstration of $\mathrm{HCV}$ viral antigen by Polymerase Chain Reaction (PCR) and the presence of Anti-HCV antibodies especially beyond the age of 18 months [22].

Because there has been no data from longterm longitudinal studies of children infected with the HCV following vertical transmission, the ultimate outcome of this mode of transmission remains largely unknown [23] Despite this, studies in some children with HCV have demonstrated histological features of chronic hepatitis, varying degrees of HCV viraemia and persistently abnormal levels of ALT $[22,24,25,26]$. In one study in Egypt, deaths from hepatocellular disease have been recorded in children who acquired HCV by vertical transmission [2].

The necessity to determine the degree of contribution of vertical transmission of HCV to childhood morbidity in the population is considered as being the justification for this study.

The aims and objectives of this study, therefore, were two-fold: to evaluate the prevalence of anti-HCV antibodies in pregnant women and their offspring (immediately after birth) at the Ladoke Akintola University Teaching Hospital, Osogbo, Osun State of Nigeria; and to suggest some means of reducing the prevalence of $\mathrm{HCV}$ infection in the population studied though limiting vertical transmission of the virus from mothers to their offspring.

\section{Materials and Methods}

The study was conducted between 1 March 2005 and 31 October 2006 at the Ladoke Akintola University of Technology Teaching Hospital, (LTH), Osogbo, Osun State, a relatively new referral medical center in Southwestern Nigeria.

The monthly antenatal clinic attendance of this institution is an average of 52 , while an average of 35 neonates are delivered monthly in the maternity unit of the hospital.

The purpose and procedures of the study were explained to pregnant women who came to register for antenatal care in the hospital within the study period. The 272 pregnant women who gave informed consent for themselves as well as for their subsequent offspring were enrolled as the subjects for the study. A simple demographic questionnaire was administered on each woman who consented.

At the time of delivery, a venous blood sample was collected from each mother and a cord blood sample was also taken from her corresponding offspring. Each blood sample was allowed to clot and retract; the serum that was subsequently obtained was stored at $-20^{\circ} \mathrm{C}$ until analyzed.

Each sample of maternal and neonatal cord sera was analyzed for anti-HCV antibodies using the Enzyme Linked Immunosorbent Assay (ELISA) method from Dialab Company, a subsidiary of Human Laboratory, Germany, at the Chemical Pathology Laboratory of the hospital. Samples that were found positive for anti-HCV antibodies were subsequently compared with positive and negative controls.

Since there were no multiple births recorded in any of the pregnant women, 272 pairs of maternal and neonatal samples were thus analyzed. The result from each maternal sample was paired with the result obtained from the cord sample of her corresponding offspring.

\section{Results}

Table 1 shows that $25(9.2 \%)$ of the 272 sera from the pregnant women were positive for antiHCV antibodies while 3 (1.1\%) of the 272 neonatal cord samples were positive for the same antibodies. Thus, the prevalence of anti-HCV 
among the pregnant mothers studied and their offspring were $9.2 \%$ and $1.1 \%$ respectively.

Table 1. Sera from Pregnant women and neonates screened for anti-HCV antibodies.

\begin{tabular}{llc} 
Serum Analyzed & Total & $\begin{array}{c}\text { Positive } \\
\text { Reaction } \\
\text { to anti-HCV } \\
\text { antibodies }\end{array}$ \\
\hline $\begin{array}{l}\text { From pregnant women in the study } \\
\begin{array}{l}\text { From cord blood of the offspring of } \\
\text { the pregnant women in the study }\end{array}\end{array}$ & 272 & $25(9.2 \%)$ \\
\hline
\end{tabular}

When the results from maternal samples and cord samples were paired, it was observed that the 3 positive cord samples were from among the offspring of the 25 pregnant mothers who were also positive for anti-HCV antibodies. Thus the prevalence of acquisition of anti-HCV antibodies or vertical transmission of HCV from mothers by the neonates in this study was $12.0 \%$.

Table 2 shows the responses of the pregnant women to the administered questionnaire. The data showed that $90.80 \%$ of the women had scarification in form of tribal marks on the face or a tattoo in other parts of the body. None of the women had a past history of blood or blood product transfusion; none had previous instrumental delivery. There was no intravenous drug user amongst them.

Table 2. Responses to questionnaire administered on 272 consenting pregnant women in the study.

\begin{tabular}{lcc}
\hline & \multicolumn{2}{c}{ Responses } \\
\cline { 2 - 3 } $\begin{array}{l}\text { Questions asked from each of } \\
\text { the 272 pregnant women }\end{array}$ & $\begin{array}{c}\text { Yes } \\
\mathbf{N}(\%)\end{array}$ & $\begin{array}{c}\text { No } \\
\mathbf{N}(\%)\end{array}$ \\
\hline $\begin{array}{l}\text { Any tattoos, scarification or tribal } \\
\text { marks? }\end{array}$ & $247(90.8)$ & $25(9.2)$ \\
$\begin{array}{l}\text { Any past history of induced } \\
\text { abortion or Caesarean section? }\end{array}$ & $0(0.0)$ & $272(100.0)$ \\
$\begin{array}{l}\text { Any past history of blood or } \\
\text { blood product transfusion? } \\
\text { Any history of intravenous drug } \\
\text { usage? }\end{array}$ & $0(0.0)$ & $272(100.0)$ \\
\hline
\end{tabular}

\section{Discussion}

A prevalence rate of $9.2 \%$ for anti-HCV antibody among pregnant women in this study is higher than that of $1 \%-2.6 \%$ earlier reported in similar studies on pregnant women from the Guinea and Côte d'Ivoire, [23,24] two countries in the same West African sub-region with Nigeria. This prevalence is, however, within the range of $3.9 \%$ to $13 \%$ reported in pregnant women from the non-West African countries of Tanzania, Egypt,
Congo, Malawi, and Cameroon [25,26,2829], These variations, noticed in different parts of subSaharan Africa, may be related to the peculiarities in the modes of transmission of HCV dictated by socio-cultural practices and environmental factors, as $90.8 \%$ of women in this study had scarification marks while none of them practiced intravenous drug usage. These disparities may also be attributed to different epidemiologic methods of study; it should be pointed out that the choice of the serological algorithm to determine $\mathrm{HCV}$ seroprevalence is of great importance in developing countries where inter-current infections contribute to false-positive Enzyme Immunoassay (EIA) results [28].

The prevalence of anti-HCV antibodies immediately after birth in neonates in this study was $1.1 \%$. If the presence of anti-HCV antibodies in the cord serum of these neonates were to be the basis for the determination of vertical transmission in the study, this would be $12 \%$. Since some of the anti-HCV antibodies may have been passively acquired from mothers seropositive for the antibodies, [29] demonstrations of viral antigenaemia in these neonates soon after birth and serially in early childhood are thus required to determine the true prevalence of vertical transmission in the population studied. The reason for this is that complete disappearance of anti-HCV antibodies have been demonstrated in some children who were initially seropositive for the antibodies as neonates [28].

This study has demonstrated that vertical transmission can be considered as a route key of $\mathrm{HCV}$ acquisition in the population studied. It is therefore suggested that wider studies should be conducted, particularly with regard to the determination of HCV RNA in both pregnant women and their offspring to ascertain the true prevalence of vertical transmission of HCV in this population. A long-term longitudinal follow-up of children who are HCV RNA positive in early life, especially following vertical transmission, is also required. In the meantime, measures such as proper screening of blood and blood products for $\mathrm{HCV}$, environmental sanitation, and the discouragement of unnecessary and unsupervised parenteral injections and skin beautification with scarification marks should be promoted as means of reducing acquiring $\mathrm{HCV}$ infection in the population. 


\section{References}

1. CPS Infectious Diseases and Immunization Committee. (1997) In Paediatrics \& Child Health 2: 227-31.

2. WHO (1999) Global surveillance and control of hepatitis C. Report of a WHO Consultation organized in collaboration with the Viral Hepatitis Prevention Board, Antwerp, Belgium. J Viral Hepatol 6: 35-47.

3. Boyer N, Marcellin P (2000) Pathogenesis, diagnosis and management of hepatitis $\mathrm{C}$. J Hepatol 32: 98-112.

4. Madhava V, Burgess C, Drucker E (2002) Epidemiology of chronic hepatitis $C$ virus infection in sub-Saharan Africa. Lancet Infect Dis 2: 293-302.

5. Wasley A, Alter MJ (2000) Epidemiology of hepatitis C: geographic differences and temporal trends. Semin Liver Dis 20:1-16.

6. Memon M, Memon M (2002) Hepatitis C: an epidemiological review. J Viral Hepatol 9 (2): 84-100.

7. Armstrong GL et al. (2006). The prevalence of Heptitis C Virus Infection in the United States, 1999 through 2002. Ann Int Med 144: 705-714.

8. Koff RS (1992) The low efficiency of maternal-neonatal transmission of hepatitis $C$ virus: How certain are we? Ann Intern Med 117:967-969.

9. Reinus JF et al. 1992. Failure to detect vertical transmission of hepatitis C virus. Ann Intern Med 117:881-886.

10. Roudot-Thoraval F et al. (1993) Lack of mother-to-infant transmission of hepatitis $\mathrm{C}$ virus in human immunodeficiency virus-seronegative women: a prospective study with hepatitis C virus RNA testing. Hepatology 17: 772-777.

11. Agha S, Sherif L, Allam M and Fawzy M (1998) Transplacental transmission of hepatitis $C$ virus in HIVnegative mothers. Res Virol. 149: 229-234.

12. Stoszek S, Fix A, Narooz S, El Kafrawy S, Saleh S, Kassern E, Hawash $Y$, Baligh $H$, El Henawy I and Thomas Strickland G (2001) Mother-to-infant HCV transmission in a Nile Delta community: preliminary results. J Hepatol. 34: 165.

13. Benjelloun S, Bahbouhi B, Sekkat S, Bennani A, Hda N and Benslimane A (1996) Anti-HCV seroprevalence and risk factors of hepatitis $C$ virus infection in Moroccan population groups. Res Virol.147: 247-255.

14. Kassem AS, el-Nawawy AA, Massoud MN, el-Nazar SY and Sobhi EM (2000) Prevalence of hepatitis C virus (HCV) infection and its vertical transmission in Egyptian pregnant women and their newborns. J Trop Pediatr. 46: 231-233.

15. Menendez C et al. (1999) Prevalence and mother-toinfant transmission of hepatitis viruses $B, C$, and $E$ in Southern Tanzania. J Med Virol. 58: 215-220.

16. Jabeen $T$ et al. (2000) Pregnancy and pregnancy outcome in hepatitis C type 1b. QJM 93: 597-601.
17. Hardikar W (2002) Hepatitis C in childhood. J Gastroenterol Hepatol 17: 476-81.

18. Paccagnini S, Principi N and Massironi E (1995) Perinatal transmission and manifestation of hepatitis $\mathrm{C}$ virus infection in a high-risk population. Pediatr Infect Dis J 14:195-199.

19. CDC Recommendations and Reports. 1998 / 47(RR19); 1-39.

20. Grayson ML et al. (1995) Breastfeeding and the risk of vertical transmission of hepatitis $\mathrm{C}$ virus. Med $\mathrm{J}$ Aust 163:107.

21. Infectious Diseases and Immunization Committee, Canadian Paediatric Society (CPS) (1997) Parent handout: Hepatitis C in pregnancy. Paediatrics \& Child Health 2 (3):227-31.

22. Resti $M$ et al. (2003) Clinical features and progression of perinatally acquired hepatitis $\mathrm{C}$ virus infection. $\mathrm{J}$ Med Virol. 70: 373-7.

23. Romero R and Lavine JE (1994) Viral hepatitis in children. Semin Liver Dis; 14: 289-302.

24. Zuccotti GV et al. (2006) Longitudinal long-term follow-up study of children with vertically acquired hepatitis $C$ virus infection. J Int Med Res. 34: 215 - 22.

25. Wejstal $\mathrm{R}$ et al. (1992). Mother-to-infant transmission of hepatitis C virus. Ann Intern Med 117:887-90.

26. Rerksuppaphol S, Hardikar W and Dore GJ (2004) Longterm outcome of vertically acquired and post transfusion hepatitis C infection in children. J Gastroenterol Hepatol. 19: 1357-62.

27. Kumar RM, Frossad PM and Hughes PF (1997) Seroprevalence and mother-to-infant transmission of hepatitis C in asymptomatic Egyptian women. Eur J Obstet Gynecol Reprod Biol 75: 177-82.

28. Raghuraman S, Subramaniam T, Daniel D, Sridharan G and Abraham P (2003) Occurrence of false positives during testing for antibodies to hepatitis $C$ virus among volunteer blood donors in India. J. Clin. Microbiol. 41: 1788-1790.

29. Ferrero S, Lungaro $P$ and Bruzzone BM (2003) Prospective study of mother-to-infant transmission of Hepatitis C virus: a 10-year survey (1990-2000). Acta Obstet Gynecol Scand 82: 229-34.

Corresponding Author: Paul Ogunro, Department of Chemical Pathology, College of Health Science, Ladoke Akintola University of Technology, Osogbo, Nigeria, Phone: 08033580043, e-mail: ogunrops@yahoo.com

Conflict of interests: The authors declare that they have no conflict of interests. 